\title{
Fatty Acid Signaling in the $\beta$-Cell and Insulin Secretion
}

\author{
Christopher J. Nolan, ${ }^{1}$ Murthy S.R. Madiraju, ${ }^{2}$ Viviane Delghingaro-Augusto, ${ }^{2}$ Marie-Line Peyot, ${ }^{2}$ and \\ Marc Prentki ${ }^{2}$
}

\begin{abstract}
$\overline{\text { Fatty acids (FAs) and other lipid molecules are important }}$ for many cellular functions, including vesicle exocytosis. For the pancreatic $\beta$-cell, while the presence of some FAs is essential for glucose-stimulated insulin secretion, FAs have enormous capacity to amplify glucose-stimulated insulin secretion, which is particularly operative in situations of $\beta$-cell compensation for insulin resistance. In this review, we propose that FAs do this via three interdependent processes, which we have assigned to a "trident model" of $\beta$-cell lipid signaling. The first two arms of the model implicate intracellular metabolism of FAs, whereas the third is related to membrane free fatty acid receptor (FFAR) activation. The first arm involves the AMP-activated protein kinase/malonyl-CoA/long-chain acyl-CoA (LC-CoA) signaling network in which glucose, together with other anaplerotic fuels, increases cytosolic malonylCoA, which inhibits FA partitioning into oxidation, thus increasing the availability of LC-CoA for signaling purposes. The second involves glucose-responsive triglyceride (TG)/free fatty acid (FFA) cycling. In this pathway, glucose promotes LC-CoA esterification to complex lipids such as TG and diacylglycerol, concomitant with glucose stimulation of lipolysis of the esterification products, with renewal of the intracellular FFA pool for reactivation to LC-CoA. The third arm involves FFA stimulation of the G-proteincoupled receptor GPR40/FFAR1, which results in enhancement of glucose-stimulated accumulation of cytosolic $\mathrm{Ca}^{2+}$ and consequently insulin secretion. It is possible that FFA released by the lipolysis arm of TG/FFA cycling is partly "secreted" and, via an autocrine/paracrine mechanism, is additive to exogenous FFAs in activating the FFAR1 pathway. Glucose-stimulated release of arachidonic acid from phospholipids by calcium-independent phospholipase $\mathrm{A}_{2}$ and/or from TG/FFA cycling may also be involved. Improved knowledge of lipid signaling in the $\beta$-cell will allow a better understanding of the mechanisms of $\beta$-cell compensation and failure in diabetes. Diabetes 55 (Suppl. 2): S16-S23, 2006
\end{abstract}

From the ${ }^{1}$ Department of Endocrinology, The Canberra Hospital, and the Medical School, The Australian National University, Garran, Australia; and the ${ }^{2}$ Molecular Nutrition Unit and the Montreal Diabetes Research Center, University of Montreal, and the Centre Hospitalier de l'Université de Montréal, Montreal, Quebec, Canada.

Address correspondence and reprint requests to Marc Prentki, CR-CHUM, Pavillon de Sève Y-4603, 1560 Sherbrooke Est, Montreal, Quebec H2L 4M1, Canada. E-mail: marc.prentki@umontreal.ca.

Received for publication 31 March 2006 and accepted in revised form 26 May 2006.

This article is based on a presentation at a symposium. The symposium and the publication of this article were made possible by an unrestricted educational grant from Servier.

AA, arachidonic acid; AMPK, AMP-activated protein kinase; CPT, carnitine palmitoyl-transferase; DAG, diacylglycerol; FA, fatty acid; FFA, free fatty acid; FFAR, free fatty acid receptor; GSIS, glucose-stimulated insulin secretion; HSL, hormone-sensitive lipase; iPLA, calcium-independent ATP-stimulated phospholipase $\mathrm{A}_{2} ; \mathrm{K}_{\mathrm{ATP}}$ channel, ATP-sensitive $\mathrm{K}^{+}$channel; LC-CoA, longchain acyl-CoA; MCD, malonyl-CoA decarboxylase; RNAi, RNA interference; TG, triglyceride.

DOI: $10.2337 / \mathrm{db} 06-\mathrm{S} 003$

(C) 2006 by the American Diabetes Association.

The costs of publication of this article were defrayed in part by the payment of page charges. This article must therefore be hereby marked "advertisement" in accordance with 18 U.S.C. Section 1734 solely to indicate this fact.

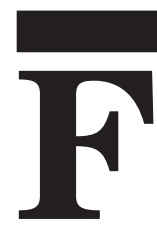

ree fatty acids (FFAs) are important to the pancreatic $\beta$-cell for its normal function, its capacity to compensate for insulin resistance, and its failure in type 2 diabetes (1-3). Fatty acid (FA) deprivation of islet tissue causes loss of glucosestimulated insulin secretion (GSIS), a process rapidly reversible by replacement with exogenous FFAs (4). In contrast, elevated FFA supply augments GSIS $(5,6)$; however, if chronically in excess, particularly in association with elevated glucose (7), saturated FFAs can reduce insulin biosynthesis (8) and secretion (3) and induce $\beta$-cell apoptosis $(2,3,7,9)$.

In this review, we consider the lipid signaling pathways involved in the FFA modulation of GSIS in healthy $\beta$-cells. By the term "lipid signaling," we refer to mechanisms by which lipid molecules, including FFA themselves, send messages to effector pathways in the cell, which in this case alter insulin vesicle exocytosis. While FFAs can signal directly via a recently discovered FFA receptor, GPR40, which is also known as free fatty acid receptor (FFAR)-1 $(10,11)$, it is also evident that intracellular metabolism of FFAs resulting in the synthesis of lipid signaling molecules such as long-chain acyl-CoA (LC-CoA) (3) and diacylglycerol (DAG) $(3,12)$ is important. As discussed, the latter involves glucose/nutrient regulation of LC-CoA partitioning within the $\beta$-cell via the AMP-activated protein kinase (AMPK)/malonyl-CoA signaling network $(3,5,13)$. This network is linked to the promotion of both intracellular FA esterification (5) and lipolysis processes (14), which together form a pathway of triglyceride (TG)/FFA cycling in the $\beta$-cell. In addition to having an important role in nutrient-secretion coupling, TG/FFA cycling may have a key role in the prevention of $\beta$-cell failure in situations of nutrient excess by preventing $\beta$-cell steatosis.

The FA supply to the $\beta$-cell can be from exogenous sources such as plasma FFAs and lipoproteins or endogenous sources such as intracellular TG and phospholipid stores. It is worth noting that islet tissue expresses lipoprotein lipase $(15,16)$. The islet, therefore, can access plasma TG as a source of FFAs, such that the FFA concentration in the immediate vicinity of $\beta$-cells is likely to be higher than that measured in plasma. The actual concentration of FFAs that $\beta$-cells are normally exposed to, however, is not known. The importance of regulated access to endogenous lipids for normal $\beta$-cell function is increasingly being realized, with particular interest currently being directed to the lipase enzymes that may be involved.

\section{NUTRIENT-SECRETION COUPLING: TRIGGERING AND AMPLIFICATION PATHWAYS}

Islet $\beta$-cell glucose metabolism is essential for the coupling of glucose sensing to insulin release $(12,17,18)$. It is well accepted that its metabolism through pyruvate to 
acetyl-CoA with subsequent mitochondrial oxidation increases the ATP/ADP ratio, which results in closure of ATP-sensitive $\mathrm{K}^{+}\left(\mathrm{K}_{\mathrm{ATP}}\right)$ channels, depolarization of the plasma membrane, opening of voltage-dependent $\mathrm{Ca}^{2+}$ channels, and $\mathrm{Ca}^{2+}$ triggering of insulin granule exocytosis $(12,19)$. This pathway, often termed the $\mathrm{K}_{\mathrm{ATP}}$ channeldependent pathway, is considered to be the major triggering pathway for GSIS $(12,19)$ (Fig. 1). In addition, pyruvate from glucose can be channeled via pyruvate carboxylase into the anaplerosis pathway, which can affect insulin secretion by increasing the levels of metabolism-derived signaling molecules such as NADPH from the malatepyruvate shuttle (20-22), citrate cataplerosis $(21,23,24)$, glutamate (25), and lipid signaling molecules from the malonyl-CoA/LC-CoA pathway $(3,5,26,27)$. These latter pathways can be considered to be amplification pathways (Fig. 1). Of particular interest in this review that focuses on lipid signaling is the role of the malonyl-CoA/LC-CoA pathway, which is considered in the next section.

\section{MALONYL-COA/LC-COA PATHWAY OF LIPID SIGNALING}

The malonyl-CoA/LC-CoA model of GSIS predicts that malonyl-CoA, derived from glucose metabolism via anaplerosis/cataplerosis $(5,27,28)$, inhibits FA oxidation by allosteric inhibition of carnitine palmitoyl-transferase (CPT)-1 (29), thereby increasing the availability of LC-CoA for lipid signaling to cellular processes involved in exocytosis. In this model (Fig. 1), the effectiveness of malonylCoA to promote insulin release depends on both a cytosolic $\mathrm{Ca}^{2+}$ rise caused by the $\mathrm{K}_{\mathrm{ATP}}$-dependent pathway and the prevailing availability of FAs to the $\beta$-cell. MalonylCoA levels are also influenced by the activity of AMPK (13). AMPK senses cellular energy status and is activated by an increase in the AMP/ATP ratio brought on by fuel deprivation, fasting or exercise $(13,30)$. AMPK activates cellular energy production (e.g., glucose oxidation and FA oxidation) and reduces energy consumption (e.g., FA synthesis and esterification) (13,30). Malonyl-CoA, on the other hand, is a "signal of plenty" and promotes nutrient storage, including FA esterification $(3,5,13)$. AMPK phosphorylates acetyl-CoA carboxylase and malonyl-CoA decarboxylase, the enzymes that regulate malonyl-CoA synthesis and degradation, respectively, with the resultant effect of lowering malonyl-CoA $(13,30)$. In addition to conditions of food deprivation and exercise, AMPK can be activated by adipokines, including adiponectin $(31,32)$ and leptin (33), and pharmacological agents such as metformin and thiazolidinediones (33,34).

The evidence supportive of a role for malonyl-CoA/LCCoA signaling in the regulation of insulin secretion is substantial. Malonyl-CoA levels have been documented to increase in response to glucose, and this precedes GSIS in $\beta$-cells $(5,24,35,36)$. Elevated glucose causes inhibition of FA oxidation $(5,37,38)$ and stimulates FA esterification processes $(5,28,36)$. Studies that have used pharmacological and/or molecular biological tools to perturb this pathway have been mostly consistent with its importance $(5,23,28,39,40)$, with few exceptions $(41,42)$. The latter two studies overexpressed malonyl-CoA decarboxylase (MCD), the enzyme that lowers malonyl-CoA levels, and showed no effect on GSIS in islets or insulinoma cell lines. GSIS, however, was assessed mostly in the absence of FFAs in these studies $(41,42)$. Considering that the malonyl-CoA/LC-CoA model proposes that malonyl-CoA signals via promoting the partitioning of FAs away from their oxidation into esterification pathways, we reexamined the effects of overexpression of MCD in the cytosol of INS832/13 $\beta$-cells and islets, but with particular focus on FFA augmentation of GSIS (5). Consistent with the earlier negative studies, MCD overexpression, despite causing a dramatic reduction in malonyl-CoA levels, had no effect on GSIS in the absence of FFAs (5). MCD expression, however, markedly diminished FFA augmentation of GSIS (5). Thus, in our opinion, the controversy raised by the above two studies $(41,42)$ has been solved by showing that inhibiting malonyl-CoA signaling by MCD overexpression results in a reduction of GSIS only under conditions in which FFAs are present in the incubation medium (5), a more "physiological" situation. This finding is also completely in keeping with the proposed model (Fig. 1) that malonyl-CoA signals by altering FA partitioning.

Consistent with the view that inhibition of FA oxidation plays a key role in the regulation of insulin secretion are the following: 1) islets from peroxisome proliferatoractivated receptor- $\alpha$-deficient mice show reduced fat oxidation and enhanced GSIS (43); 2) overexpression of peroxisome proliferator-activated receptor- $\alpha$ in the $\beta$-cell causes reduction in GSIS (44); 3) hyperinsulinemic hypoglycemia has been observed in subjects with shortchain L-3-hydroxyacyl-CoA dehydrogenase deficiency that causes impaired FA oxidation (45); 4) the FA oxidation inhibitor 2-bromopalmitate restores GSIS in fasted rat islets in which fat oxidation is known to be increased (12); and 5) overexpression of a malonyl-CoA-insensitive CPT-1 mutant in INS832/13 cells and rat islets, which predictably caused failure of glucose to inhibit FA oxidation, curtailed GSIS (39).

Another important finding from our study of cytosolic MCD overexpression (5) was that FFAs markedly amplified insulin secretion in response to all fuel and non-fuel stimuli and that this was dependent on a normal malonylCoA/LC-CoA signaling pathway. It should be underscored that in vitro islet experiments have traditionally been carried out in the absence of exogenous FFAs, a situation that may lead to a reduction or suppression of normal $\beta$-cell signaling processes, in particular those involving lipid signaling. Thus, we recommend that insulin secretion studies be performed in vitro with FFAs present.

\section{TG/FFA CYCLING AND INSULIN SECRETION}

In addition to FA oxidation and esterification, lipolysis is the third major pathway of intracellular FA partitioning. Lipolysis of intracellular TG refers to the hydrolytic removal of the fatty-acyl chains from the glycerol backbone by lipase enzymes. Of particular interest to this discussion on FA signaling is the recent finding that both FA esterification and lipolysis processes are glucose-responsive in the $\beta$-cell (Fig. 1). We recently demonstrated that glucose increased lipolysis, as determined by glycerol release, in islets from both wild-type and hormone-sensitive lipase (HSL) null mice (14). Another group similarly demonstrated glucose stimulation of lipolysis in isolated islets from rats (46). Furthermore, we recently showed that glucose-responsive FA esterification and lipolysis processes are increased by approximately threefold in islets of the nondiabetic severely insulin-resistant Zucker fatty rat, which, unlike the Zucker diabetic fatty rat, maintains normoglycemia by sustained $\beta$-cell compensation with insulin hypersecretion (1). These findings are consistent with the presence of glucose-responsive TG/FFA cycling in 


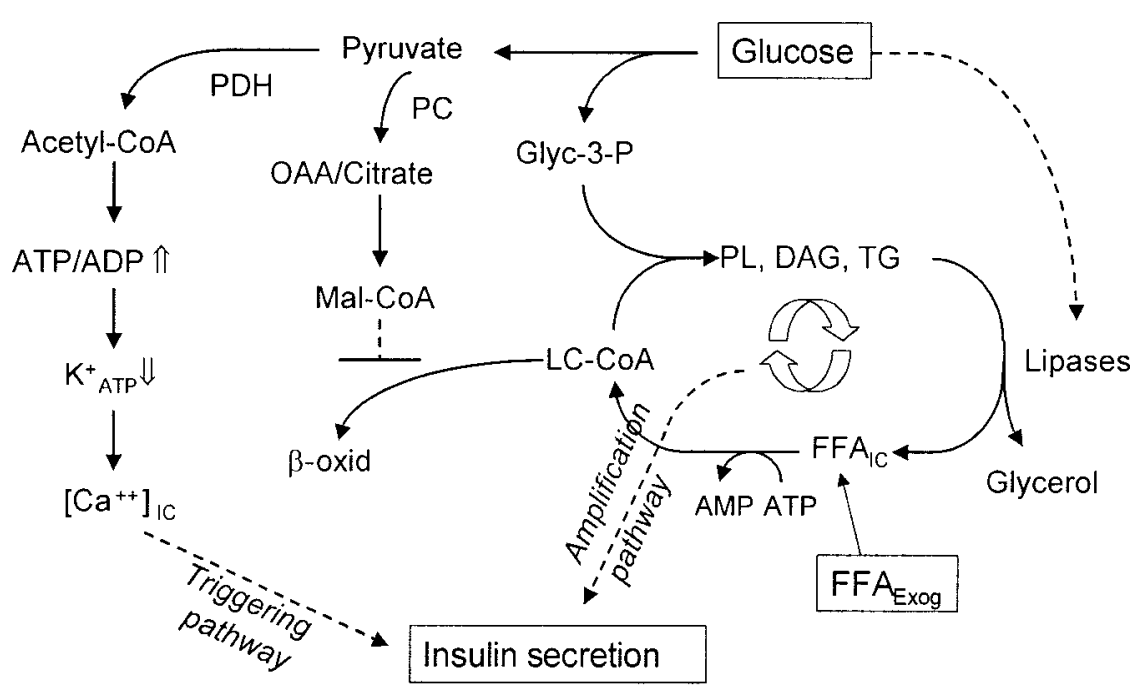

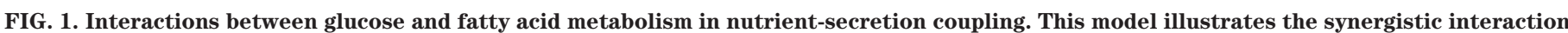

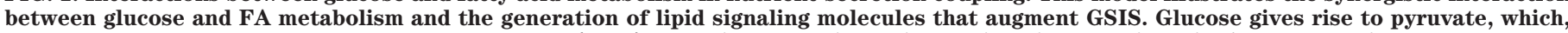

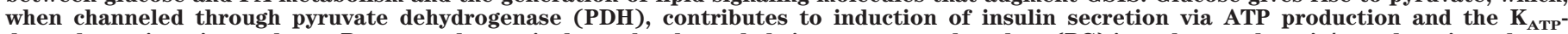

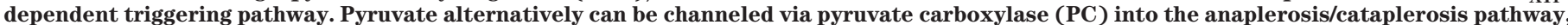

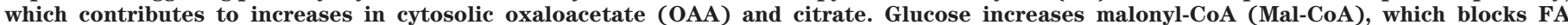

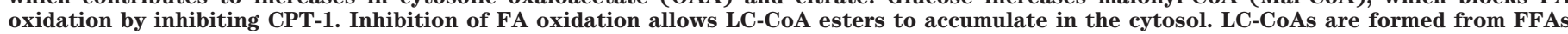

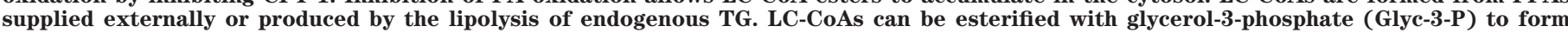

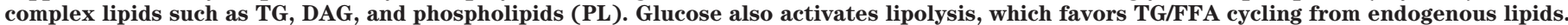

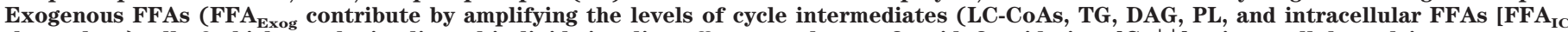
themselves), all of which may be implicated in lipid signaling effector pathways. $\beta-o x i d, \beta-o x i d a t i o n ; ~\left[C a^{++}\right]_{I_{C}}$, intracellular calcium.

pancreatic $\beta$-cells. To verify that TG/FFA cycling exists in insulin-secreting cells, we performed a series of radioactive tracer pulse-chase experiments in INS832/13 $\beta$-cells in which either the acyl chains or the glycerol backbone were labeled. During the chase period, label from the acyl moieties of TG fell at a substantially slower rate (41\% in 20 $\mathrm{min}$ ) than labeling of the glycerol moiety (60\% in $20 \mathrm{~min}$ ), consistent with acyl chain recycling (C.J.N., M.P., unpublished data).

The potential importance of this pathway in lipid signaling for insulin secretion comes from studies in which lipolysis is inhibited. GSIS is markedly curtailed in rat islets by inhibition of lipolysis by the potent inhibitors orlistat (46) and 3,5-dimethylpyrazole (47). We have also shown that FFA augmentation of GSIS in isolated Zucker fatty islets is reduced by $50 \%$ by orlistat (1). Unclear, however, is the mechanism by which TG/FFA cycling, including lipolysis, contributes to FFA amplification of GSIS. Elevated glucose, particularly in the presence of exogenous FFAs, will result in increased levels of all lipid moieties within the cycle, including LC-CoA, DAG, phospholipids, and FFAs (Fig. 1). Insulin vesicle exocytosis is a complex process involving many steps, including vesicle movement, docking, priming, and finally fusion with the plasma membrane (48). Some of these steps could be modulated by TG/FFA cycle intermediates acting as lipid signaling molecules. For example, LC-CoA can be used to acylate proteins, such as the synaptosomal-associated protein-25 (49) and synaptogamin (50), which can enhance their association with target membranes. Interestingly, LC-CoA has also been shown to activate lipases from islet tissue (51). As such, a mediator of glucose-induced lipolysis could be elevated LC-CoA themselves. DAG, the levels of which rise in the $\beta$-cell in response to glucose $(36,52)$, not only activate protein kinase $\mathrm{C}$, which is implicated in insulin secretion (53), but also bind to the $C_{1}$ domain of the synaptic vesicle priming protein Munc-13 (54), which has recently been shown to be important for normal insulin secretion $(55,56)$. Thus, heterozygous Munc-13-1 $1^{+-}$mice show reduced GSIS, both in vivo and in isolated islets (56), such that Munc-13 is a prime candidate as an effector molecule in $\beta$-cell lipid signaling. TG/FFA will also affect membrane glycerophospholipid metabolism, which could influence secretion via alteration of membrane physicochemical properties (57). The glycerophospholipids may also have more direct effects (58), as is discussed below in the sections on fatty acid receptor signaling and phospholipase $A_{2}$. It may be that the TG/FFA cycle is a means of targeting the delivery of FFAs, and perhaps specific FFAs such as arachidonic acid (AA), to a particular subcellular site within the $\beta$-cell. Of relevance to this, HSL has been shown to be colocalized with insulin vesicles (59).

The key regulatory lipase enzyme(s) of the islet TG/FFA cycle is uncertain. The importance of HSL in the islet is unclear, such that there is current interest in searching for alternate lipases. HSL is expressed in the islet (60) and has been shown to be upregulated by persistently elevated glucose levels (61). Zucker fatty rat islets, which compensate for insulin resistance with insulin hypersecretion, also appear to have increased expression of HSL at the mRNA level, which correlates with the enhanced islet TG/FFA cycling in this model (1). Against a significant role for HSL, however, are studies in the HSL null mouse model $(14,62)$. In one study, lipolysis and GSIS was not at all impaired in HSL null mice (62), suggesting that HSL is not important. In another study from our group, GSIS was shown to be considerably impaired, but only in fasted male mice; all female and fed male mice had normal GSIS (14). Furthermore, lipolysis could be still measured in these mice, and as stated above, glucose was shown to enhance it (14), a clear indication for alternate enzymes controlling $\beta$-cell lipolysis. These may include the newly described lipases that contain a patatin-like domain such as adipose tissue TG lipase (also called desnutrin) (63-65), adiponutrin 
(66), and GS2 (67). Another possibility is carboxylesterase 3 , also called TG hydrolase (68). These newly described lipases show much higher activity for TG rather than DAG $(63,65,67,68)$ as compared with HSL, which primarily hydrolyzes DAG, monoacylglycerol, and cholesteryl esters $(63,69)$. Clearly, more work is needed to delineate the roles of lipases in the $\beta$-cell.

Another unexpected finding in the studies of Zucker fatty rat islets and INS832/13 cells was that the flux of glucose carbons via the glycerol backbone of glycerolipids accounts for a substantial proportion of total glycolytic flux. At $16 \mathrm{mmol} / \mathrm{l}$ glucose, we estimated that 13 and $25 \%$ of the total glucose utilization by Zucker lean and Zucker fatty rat islets, respectively, could be accounted for by glycerol released into the media. Because islets do not contain glycerokinase (70), glycerol released from the lipolysis arm of TG/FFA cycling escapes the cell, since it cannot be reactivated to glycerol-3-phosphate. For INS832/13 cells incubated at 2 or $10 \mathrm{mmol} / \mathrm{l}$ glucose, 15 and $38 \%$, respectively, of total glucose carbon flux was via this pathway (C.J.N., M.P., unpublished data). The TG/FFA cycle of $\beta$-cells, therefore, appears to be a major and hitherto overlooked pathway for both glucose and FFA metabolism.

There are two conceivable advantages for the $\beta$-cell to use glucose in this way. First, glucose usage via the TG/FFA cycle provides an alternative pathway by which glucose metabolism may be coupled to insulin secretion, which, via the provision of lipid-signaling molecules, allows amplification of the triggering pathway for exocytosis. The second is related to the preservation of $\beta$-cell mass in the face of fuel surfeit as occurs in obesity and diabetes. Thus, nutrient toxicity to cells occurs when the flux of metabolites through mitochondrial oxidation is high, since this causes the production of damaging superoxides and reactive oxygen species (71-73). Thus, glucose flux through TG/FFA cycling is a means of nutrient-secretion coupling that bypasses the need for oxidation to cause secretion and allows for detoxification of glucose carbons in the form of glycerol that is released from the $\beta$-cell, as discussed above. Furthermore, use of ATP by the cycle will reduce the mitochondrial membrane potential and, in this way, lessen the rate of reactive oxygen species production (74).

\section{AA SIGNALING AND PHOSPHOLIPASE $\mathrm{A}_{\mathbf{2}}$}

AA is a major acyl component of glycerolipids, constituting $>30 \%$ of the glycerolipid fatty acid mass in rodent islets (75). Furthermore, glucose stimulation of $\beta$-cells is accompanied by release of free AA from glycerolipids, and inhibition of AA release impairs GSIS $(75,76)$. The exact relationship between AA and insulin secretion, however, has been a matter of speculation. AA release depends on $\beta$-cell metabolism of glucose (76), and it has been shown that exogenous AA is capable of causing a rise in cytosolic $\mathrm{Ca}^{2+}$ (77). Importantly, AA is substrate for the synthesis of eicosanoid signaling molecules (78). Lysophosphatidic acids, produced in addition to AA by the action of phospholipase A isoforms on membrane phospholipids, also have signaling actions (78). Although it was thought that glucose-stimulated AA release is from hydrolysis of membrane phospholipids (75-79), another possibility is that it is from hydrolysis of TG within the TG/FFA cycling pathway. It is noteworthy that in many cell types (80), and in INS832/13 cells (M.S.R.M., M.P., unpublished data), externally added AA is incorporated into both TG and phospholipids. Also, AA is predominantly incorporated into TG first, whereas AA for phospholipid biosynthesis and remodeling of membrane phospholipids is from TG lipolysis and TG/FFA cycling (80-82).

Calcium-independent ATP-stimulated phospholipase $\mathrm{A}_{2}$ $\left(\mathrm{iPLA}_{2}\right)$ isoenzymes have been implicated in glucose-stimulated AA release $(76,77)$, since glucose activates AA release in the absence of $\mathrm{Ca}^{2+}$ (83), and the pharmacological iPLA ${ }_{2 \beta}$ inhibitor, bromoenol lactone suicide substrate, inhibits AA release and GSIS in vitro $(76,77)$ and insulin secretion and glucose tolerance in vivo (77). While the effect of bromoenol lactone suicide substrate was taken as evidence that $\mathrm{iPLA}_{2 \beta}$ was the responsible enzyme increasing AA release, bromoenol lactone suicide substrate also has an inhibitory effect on desnutrin/adipose tissue TG lipase, adiponutrin, and GS2, which are able to hydrolyze TG (84). These newly described lipases have an iPLA $_{2}$ signature motif and are also known as $\mathrm{PPLA}_{2 \varepsilon}, \mathrm{iPLA}_{2 \eta}$, and iPLA $_{2 \varsigma}$, respectively (84), but their activity on hydrolysis of phospholipid is 100 - to 500 -fold lower than that of their TG lipase activity (84). Furthermore, bromoenol lactone suicide substrate also inhibits phosphatidate phosphohydrolase (85), which is an important enzyme in TG synthesis. It therefore cannot be excluded that bromoenol lactone suicide substrate may act by inhibition of these alternative lipases and release of AA via TG/FFA cycling.

RNAi-knockdown of iPLA ${ }_{2 \beta}$ in INS1 cells resulted in decreased insulin secretion, but without effect on the content or composition of its glycerophospholipids (86). This again raises doubt on the role of $\mathrm{PLA}_{2}$-mediated phospholipid hydrolysis in the control of GSIS. The role of other types of phospholipase enzymes are also not clear. Overexpression of cytosolic PLA $\mathrm{PL}_{2 \alpha}$ has been shown to enhance insulin exocytosis from mouse $\beta$-cells, probably via the release of AA (87), but involvement of cytosolic $\mathrm{PLA}_{2 \alpha}$ in the regulation of insulin secretion has also been questioned $(88,89)$. Excess production of AA by the $\beta$-cells may also be detrimental for normal secretory and metabolic functions (89). Clearly, further investigation into the roles of phospholipid, phospholipases, and AA signaling, including interactions between phospholipid and TG metabolism, is warranted.

\section{FATTY ACIDS AND LIPID RECEPTOR SIGNALING}

Recently, it was discovered that FFAs were the natural ligands for a small group of previously orphaned Gprotein-coupled transmembrane receptors, including GPR40/FFAR1 (11). In one of the first reports, FFAR1 was shown to be highly expressed in rodent pancreatic $\beta$-cells (10), and its downregulation by RNAi caused impaired FA augmentation of insulin secretion (10). FFAR1 has also been documented to be highly expressed in human $\beta$-cells (90). Activation of FFAR1 by FFAs causes an increase in intracellular $\mathrm{Ca}^{2+}$ levels, which is believed to be via activation of the Goq-phospholipase C pathway with release of $\mathrm{Ca}^{2+}$ from the endoplasmic reticulum (91). The capacity for FFAs to increase cytosolic $\mathrm{Ca}^{2+}$, however, also depends on glucose activation of L-type $\mathrm{Ca}^{2+}$ channels and the presence of extracellular $\mathrm{Ca}^{2+}$ (91). FFAR1 activation, via $\mathrm{Ca}^{2+}$ release from the endoplasmic reticulum, may potentiate glucose-induced activity of L-type $\mathrm{Ca}^{2+}$ channels (91), with the end result of enhanced $\mathrm{Ca}^{2+}$ uptake from the extracellular $\mathrm{Ca}^{2+}$ pool, which then affects exocytosis. Studies in GPR40/FFAR1-deficient mice 
confirmed a role for this receptor in FFA augmentation of insulin secretion (92). GPR40 deficiency protected the mice from the harmful metabolic effects of high-fat feeding (92). Conversely, overexpression of GPR40, led to liver steatosis, impairment of islet function, and diabetes (92). FFAR1, therefore, may be one of the links between fuel surfeit and $\beta$-cell failure in obesity-associated type 2 diabetes in genetically susceptible individuals (92). Whether FFAR1 plays a role in the $\beta$-cell compensation processes and the control of $\beta$-cell growth remains to be investigated. In relation to FFAR1 and cell growth, we recently showed that FFAR1/ GPR40 mediates the action of oleate to promote proliferation of breast cancer cells in vitro (93).

Another G-protein-coupled transmembrane receptor that may have a role in lipid signaling in $\beta$-cells is GPR119. This G-protein-coupled transmembrane receptor is expressed particularly in the gastrointestinal tract and pancreas (94), including islet $\beta$-cells (58). Its natural ligand is oleoylethanolamide (94); however, lysophosphatidylcholine is also known to have some stimulatory activity (58), including enhancement of GSIS (58). The direct effects on islets of oleoylethanolamide, the true ligand of GPR119, have not been studied so far. Because the formation of oleoylethanolamide and related compounds is coupled to membrane phospholipid metabolism, it is likely that fuel stimuli that alter TG/FFA cycling also influence the levels of oleoylethanolamide, and this may have modulatory effects on insulin secretion.

\section{REFINED MODEL OF LIPID SIGNALING IN NUTRIENT-SECRETION COUPLING}

We now have a more advanced, but as yet incomplete understanding of lipid signaling in nutrient-secretion cou- pling for insulin secretion. FFAs are involved in amplification of GSIS that is triggered by the $\mathrm{K}_{\mathrm{ATP}}$-dependent pathway. This involves indirect signaling that requires intracellular FA metabolism, which implicates both the anaplerotic/malonyl-CoA pathway and intracellular TG/ FFA cycling, as depicted in Fig. 1. The model needs to be extended, however, to include direct signaling via FFAR1/ GPR40. We propose that lipid signaling in the $\beta$-cell involves three arms (trident model) that comprise signaling via glucose-derived malonyl-CoA, TG/FFA cycling including lipolysis, and FFAR1 (Fig. 2). In this view, signaling via the AMPK/malonyl-CoA/CPT-1 network and TG/FFA cycling are tightly linked processes. Glucose promotes activity in the TG/FFA cycle by elevating malonyl-CoA, which inhibits partitioning of LC-CoA to FA oxidation (via CPT-1 inhibition), such that LC-CoAs are more available for esterification processes. Glucose also provides the glycerol-3-phosphate necessary for FA esterification into complex lipids. Lastly, glucose activates lipase enzyme(s), possibly through a direct effect of LCCoA on the activity of lipases (51), although confirmation of this and assessment of other potential mechanisms are needed. A reduction in AMPK activity promoted by fuel stimulation that would enhance $\beta$-cell lipolysis is an alternative possibility in view that AMPK activation has been associated with reduced lipolysis in adipocytes $(95,96)$. While glucose, by activating lipolysis, promotes TG/FFA cycling from endogenous lipid stores, the provision of exogenous FFA supply to the $\beta$-cell will amplify the pathway, increasing the intracellular concentrations of the lipid signals LC-CoA, DAG, phospholipids, and unesterified FFAs.

This refined model (Figs. 1 and 2) reconciles a potential

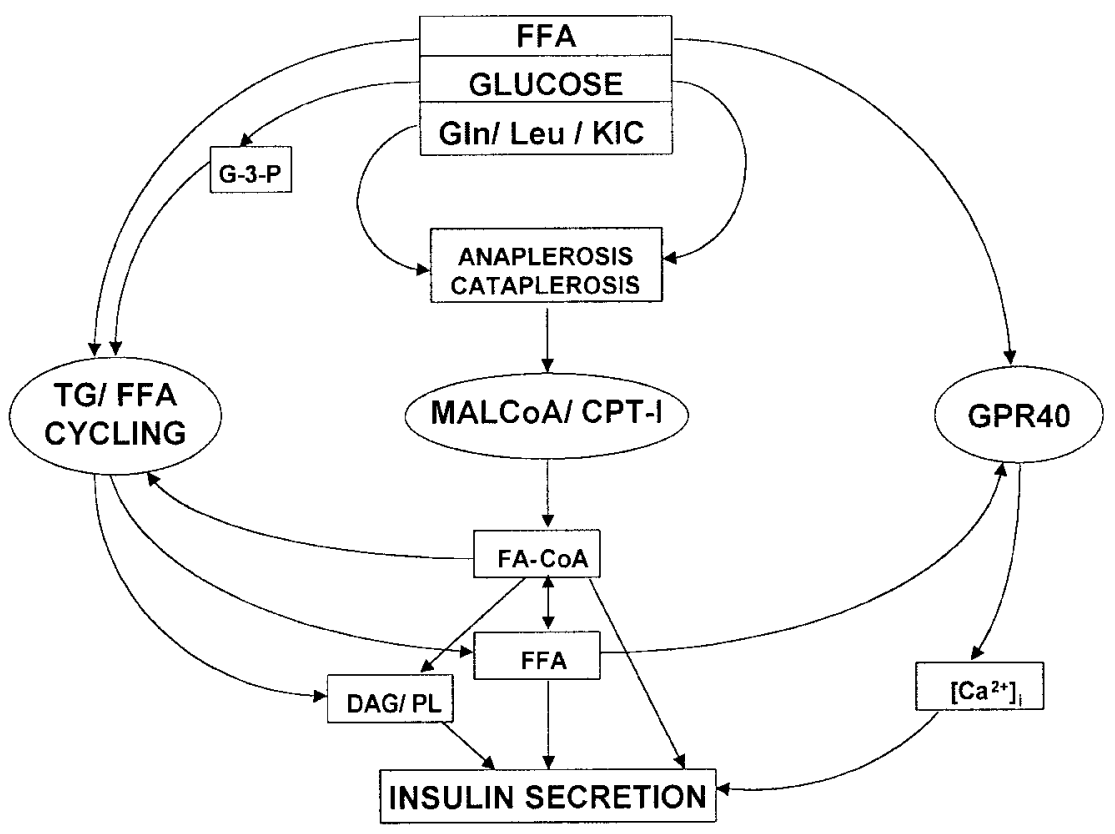

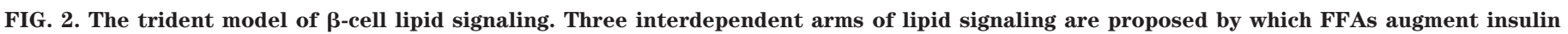

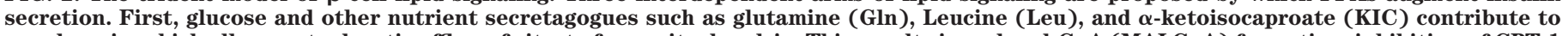

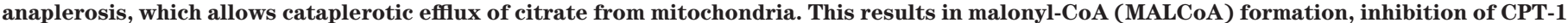

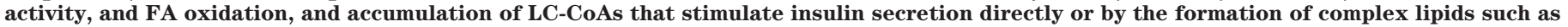

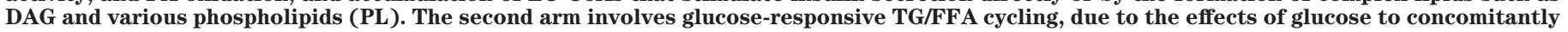

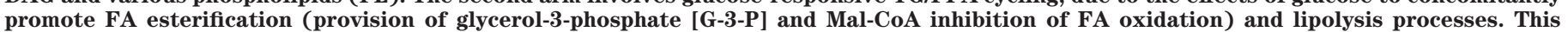

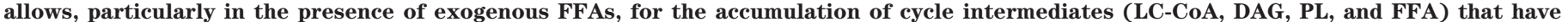

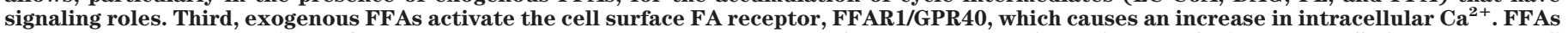

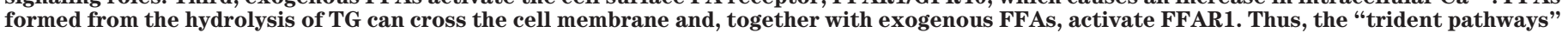
of lipid amplification intercommunicate and synergize to promote insulin secretion. 
caveat of the malonyl-CoA model alone, namely that in some $(97,98)$ (J. Lamontagne, M.P., unpublished data), but not all $(38,44)$, studies, the FA oxidation inhibitors etomoxir and bromopalmitate did not promote insulin secretion. The explanation can be found in the interaction between the TG/FFA cycling and malonyl-CoA/CPT-1 pathways. Thus, lipid signaling molecules (FFA and DAG) released from endogenous TG stores by glucose-induced lipolysis can be sustained because FA oxidation is simultaneously inhibited by the rise in malonyl-CoA. In other words, if malonyl-CoA would not rise simultaneously with enhanced lipolysis, the released FFA and derived signals would be degraded via the CPT-1/FA oxidation pathway. An additional way to formulate this novel view that reconciles these contradictions in the literature $(97,98)$ is to propose that the primary "on" signal of glucose, as far as lipid signaling is concerned, is enhanced lipolysis, whereas the rise in malonyl-CoA and CPT-1 inhibition mediate the suppression of an "off" signal (FA oxidation/degradation). Thus, inhibition of FA oxidation, per se, by agents such as etomoxir may not promote insulin secretion because they do not also activate lipolysis.

It should be underscored that TG/FFA and malonyl-CoA signaling are likely linked to FFAR1/GPR40 signaling, because FFAs released from lipolysis can be "secreted" from the $\beta$-cell and stimulate the cell surface receptor in an autocrine/paracrine manner (Fig. 2). In support of this, FFA release from islets in response to elevated glucose has been observed (99). While it seems likely that FFA signaling via FFAR1 involves increases in intracellular $\mathrm{Ca}^{2+}$, the mechanisms by which TG/FFA cycling provides signals for insulin secretion are poorly understood and are likely to be multiple. As discussed above, they may involve protein acylation $(3,100)$, the DAG receptor Munc-13 (56), and atypical C-kinase enzymes activated by LC-CoA (101). The lipase enzymes involved remain to be determined. It is essential that all aspects of lipid signaling in normal insulin secretion are solved such that the pathophysiological mechanisms of $\beta$-cell failure in obesity-associated type 2 diabetes can be more fully understood.

\section{ACKNOWLEDGMENTS}

This work was supported by grants from Genome Quebec, Canada; the National Institutes of Health (DK-63356); the Canadian Institute of Health Research; and The Canberra Hospital Private Practice Fund, ACT, Australia.

\section{REFERENCES}

1. Nolan CJ, Leahy JL, Delghingaro-Augusto V, Moibi J, Soni K, Peyot M-L, Fortier M, Guay C, Lamontagne J, Barbeau A, Przybytkowski E, Joly E, Masiello P, Wang S, Mitchell GA, Prentki M: Beta-cell compensation for insulin resistance in Zucker fatty rats: increased lipolysis and fatty acid signalling. Diabetologia 49:2120-2130, 2006

2. McGarry JD: Banting Lecture 2001: Dysregulation of fatty acid metabolism in the etiology of type 2 diabetes. Diabetes 51:7-18, 2002

3. Prentki M, Joly E, El-Assaad W, Roduit R: Malonyl-CoA signaling, lipid partitioning, and glucolipotoxicity: role in beta-cell adaptation and failure in the etiology of diabetes. Diabetes 51 (Suppl. 3):S405-S413, 2002

4. Stein DT, Esser V, Stevenson BE, Lane KE, Whiteside JH, Daniels MB, Chen S, McGarry JD: Essentiality of circulating fatty acids for glucosestimulated insulin secretion in the fasted rat. J Clin Invest 97:2728-2735, 1996

5. Roduit R, Nolan C, Alarcon C, Moore P, Barbeau A, Delghingaro-Augusto V, Przybykowski E, Morin J, Masse F, Massie B, Ruderman N, Rhodes C, Poitout V, Prentki M: A role for the malonyl-CoA/long-chain acyl-CoA pathway of lipid signaling in the regulation of insulin secretion in response to both fuel and nonfuel stimuli. Diabetes 53:1007-1019, 2004
6. Crespin SR, Greenough WB 3rd, Steinberg D: Stimulation of insulin secretion by infusion of free fatty acids. J Clin Invest 48:1934-1943, 1969 7. El-Assaad W, Buteau J, Peyot ML, Nolan C, Roduit R, Hardy S, Joly E, Dbaibo G, Rosenberg L, Prentki M: Saturated fatty acids synergize with elevated glucose to cause pancreatic beta-cell death. Endocrinology 144:4154-4163, 2003

8. Poitout V, Hagman D, Stein R, Artner I, Robertson RP, Harmon JS: Regulation of the insulin gene by glucose and fatty acids. J Nutr 136:873-876, 2006

9. Lee Y, Hirose H, Ohneda M, Johnson JH, McGarry JD, Unger RH: Beta-cell lipotoxicity in the pathogenesis of non-insulin-dependent diabetes mellitus of obese rats: impairment in adipocyte-beta-cell relationships. Proc Natl Acad Sci U S A 91:10878-10882, 1994

10. Itoh Y, Kawamata Y, Harada M, Kobayashi M, Fujii R, Fukusumi S, Ogi K, Hosoya M, Tanaka Y, Uejima H, Tanaka H, Maruyama M, Satoh R, Okubo S, Kizawa H, Komatsu H, Matsumura F, Noguchi Y, Shinohara T, Hinuma S, Fujisawa Y, Fujino M: Free fatty acids regulate insulin secretion from pancreatic beta cells through GPR40. Nature 422:173-176, 2003

11. Briscoe CP, Tadayyon M, Andrews JL, Benson WG, Chambers JK, Eilert MM, Ellis C, Elshourbagy NA, Goetz AS, Minnick DT, Murdock PR, Sauls HR Jr, Shabon U, Spinage LD, Strum JC, Szekeres PG, Tan KB, Way JM, Ignar DM, Wilson S, Muir AI: The orphan G protein-coupled receptor GPR40 is activated by medium and long chain fatty acids. J Biol Chem 278:11303-11311, 2003

12. Prentki M: New insights into pancreatic beta-cell metabolic signaling in insulin secretion. Eur J Endocrinol 134:272-286, 1996

13. Ruderman N, Prentki M: AMP kinase and malonyl-CoA: targets for therapy of the metabolic syndrome. Nat Rev Drug Discov 3:340-351, 2004

14. Peyot ML, Nolan CJ, Soni K, Joly E, Lussier R, Corkey BE, Wang SP, Mitchell GA, Prentki M: Hormone-sensitive lipase has a role in lipid signaling for insulin secretion but is nonessential for the incretin action of glucagon-like peptide 1. Diabetes 53:1733-1742, 2004

15. Cruz WS, Kwon G, Marshall CA, McDaniel ML, Semenkovich CF: Glucose and insulin stimulate heparin-releasable lipoprotein lipase activity in mouse islets and INS-1 cells: a potential link between insulin resistance and beta-cell dysfunction. J Biol Chem 276:12162-12168, 2001

16. Pappan KL, Pan Z, Kwon G, Marshall CA, Coleman T, Goldberg IJ, McDaniel ML, Semenkovich CF: Pancreatic beta-cell lipoprotein lipase independently regulates islet glucose metabolism and normal insulin secretion. J Biol Chem 280:9023-9029, 2005

17. Newgard CB, McGarry JD: Metabolic coupling factors in pancreatic beta-cell signal transduction. Annu Rev Biochem 64:689-719, 1995

18. Meglasson MD, Matschinsky FM: Pancreatic islet glucose metabolism and regulation of insulin secretion. Diabetes Metab Rev 2:163-214, 1986

19. Ashcroft FM, Rorsman P: ATP-sensitive K+ channels: a link between B-cell metabolism and insulin secretion. Biochem Soc Trans 18:109-111, 1990

20. MacDonald MJ: Feasibility of a mitochondrial pyruvate malate shuttle in pancreatic islets: further implication of cytosolic NADPH in insulin secretion. J Biol Chem 270:20051-20058, 1995

21. Cline GW, Lepine RL, Papas KK, Kibbey RG, Shulman GI: 13C NMR isotopomer analysis of anaplerotic pathways in INS-1 cells. J Biol Chem 279:44370-44375, 2004

22. Lu D, Mulder H, Zhao P, Burgess SC, Jensen MV, Kamzolova S, Newgard $\mathrm{CB}$, Sherry AD: $13 \mathrm{C} \mathrm{NMR}$ isotopomer analysis reveals a connection between pyruvate cycling and glucose-stimulated insulin secretion (GSIS). Proc Natl Acad Sci U S A 99:2708-2713, 2002

23. Flamez D, Berger V, Kruhoffer M, Orntoft T, Pipeleers D, Schuit FC: Critical role for cataplerosis via citrate in glucose-regulated insulin release. Diabetes 51:2018-2024, 2002

24. Farfari S, Schulz V, Corkey B, Prentki M: Glucose-regulated anaplerosis and cataplerosis in pancreatic beta-cells: possible implication of a pyruvate/citrate shuttle in insulin secretion. Diabetes 49:718-726, 2000

25. Maechler P, Wollheim CB: Mitochondrial glutamate acts as a messenger in glucose-induced insulin exocytosis. Nature 402:685-689, 1999

26. Liu YQ, Jetton TL, Leahy JL: $\beta$-Cell adaptation to insulin resistance: increased pyruvate carboxylase and malate-pyruvate shuttle activity in islets of nondiabetic Zucker fatty rats. J Biol Chem 277:39163-39168, 2002

27. Prentki M, Corkey BE: Are the beta-cell signaling molecules malonyl-CoA and cystolic long-chain acyl-CoA implicated in multiple tissue defects of obesity and NIDDM? Diabetes 45:273-283, 1996

28. Prentki M, Vischer S, Glennon MC, Regazzi R, Deeney JT, Corkey BE: Malonyl-CoA and long chain acyl-CoA esters as metabolic coupling factors in nutrient-induced insulin secretion. J Biol Chem 267:5802-5810, 1992

29. McGarry JD, Brown NF: The mitochondrial carnitine palmitoyltrans- 
ferase system: from concept to molecular analysis. Eur J Biochem 244:1-14, 1997

30. Kahn BB, Alquier T, Carling D, Hardie DG: AMP-activated protein kinase: ancient energy gauge provides clues to modern understanding of metabolism. Cell Metab 1:15-25, 2005

31. Tomas E, Tsao TS, Saha AK, Murrey HE, Zhang CC, Itani SI, Lodish HF, Ruderman NB: Enhanced muscle fat oxidation and glucose transport by ACRP30 globular domain: acetyl-CoA carboxylase inhibition and AMPactivated protein kinase activation. Proc Natl Acad Sci U S A 99:1630916313,2002

32. Yamauchi T, Kamon J, Minokoshi Y, Ito Y, Waki H, Uchida S, Yamashita S, Noda M, Kita S, Ueki K, Eto K, Akanuma Y, Froguel P, Foufelle F, Ferre P, Carling D, Kimura S, Nagai R, Kahn BB, Kadowaki T: Adiponectin stimulates glucose utilization and fatty-acid oxidation by activating AMP-activated protein kinase. Nat Med 8:1288-1295, 2002

33. Minokoshi Y, Kim YB, Peroni OD, Fryer LG, Muller C, Carling D, Kahn BB: Leptin stimulates fatty-acid oxidation by activating AMP-activated protein kinase. Nature 415:339-343, 2002

34. Fryer LG, Parbu-Patel A, Carling D: The anti-diabetic drugs rosiglitazone and metformin stimulate AMP-activated protein kinase through distinct signaling pathways. J Biol Chem 277:25226-25232, 2002

35. Liang Y, Matschinsky FM: Content of CoA-esters in perifused rat islets stimulated by glucose and other fuels. Diabetes 40:327-333, 1991

36. Corkey BE, Glennon MC, Chen KS, Deeney JT, Matschinsky FM, Prentki $\mathrm{M}$ : A role for malonyl-CoA in glucose-stimulated insulin secretion from clonal pancreatic beta-cells. J Biol Chem 264:21608-21612, 1989

37. Segall L, Lameloise N, Assimacopoulos-Jeannet F, Roche E, Corkey P, Thumelin S, Corkey BE, Prentki M: Lipid rather than glucose metabolism is implicated in altered insulin secretion caused by oleate in INS-1 cells. Am J Physiol 277:E521-E528, 1999

38. Chen S, Ogawa A, Ohneda M, Unger RH, Foster DW, McGarry JD: More direct evidence for a malonyl-CoA-carnitine palmitoyltransferase I interaction as a key event in pancreatic beta-cell signaling. Diabetes 43:878883,1994

39. Herrero L, Rubi B, Sebastian D, Serra D, Asins G, Maechler P, Prentki M, Hegardt FG: Alteration of the malonyl-CoA/carnitine palmitoyltransferase I interaction in the beta-cell impairs glucose-induced insulin secretion. Diabetes 54:462-471, 2005

40. Zhang S, Kim KH: Essential role of acetyl-CoA carboxylase in the glucose-induced insulin secretion in a pancreatic beta-cell line. Cell Signal 10:35-42, 1998

41. Antinozzi PA, Segall L, Prentki M, McGarry JD, Newgard CB: Molecular or pharmacologic perturbation of the link between glucose and lipid metabolism is without effect on glucose-stimulated insulin secretion: a reevaluation of the long-chain acyl-CoA hypothesis. J Biol Chem 273: 16146-16154, 1998

42. Mulder H, Lu D, Finley JT, An J, Cohen J, Antinozzi PA, McGarry JD, Newgard CB: Overexpression of a modified human malonyl-CoA decarboxylase blocks the glucose-induced increase in malonyl-CoA level but has no impact on insulin secretion in INS-1-derived (832/13) beta-cells. J Biol Chem 276:6479-6484, 2001

43. Gremlich S, Nolan C, Roduit R, Burcelin R, Peyot ML, DelghingaroAugusto V, Desvergne B, Michalik L, Prentki M, Wahli W: Pancreatic islet adaptation to fasting is dependent on peroxisome proliferator-activated receptor alpha transcriptional up-regulation of fatty acid oxidation. Endocrinology 146:375-382, 2005

44. Tordjman K, Standley KN, Bernal-Mizrachi C, Leone TC, Coleman T, Kelly DP, Semenkovich CF: PPARalpha suppresses insulin secretion and induces UCP2 in insulinoma cells. J Lipid Res 43:936-943, 2002

45. Molven A, Matre GE, Duran M, Wanders RJ, Rishaug U, Njolstad PR, Jellum E, Sovik O: Familial hyperinsulinemic hypoglycemia caused by a defect in the SCHAD enzyme of mitochondrial fatty acid oxidation. Diabetes 53:221-227, 2004

46. Mulder H, Yang S, Winzell MS, Holm C, Ahren B: Inhibition of lipase activity and lipolysis in rat islets reduces insulin secretion. Diabetes 53:122-128, 2004

47. Masiello P, Novelli M, Bombara M, Fierabracci V, Vittorini S, Prentki M, Bergamini E: The antilipolytic agent 3,5-dimethylpyrazole inhibits insulin release in response to both nutrient secretagogues and cyclic adenosine monophosphate agonists in isolated rat islets. Metabolism 51:110-114, 2002

48. Bratanova-Tochkova TK, Cheng H, Daniel S, Gunawardana S, Liu YJ, Mulvaney-Musa J, Schermerhorn T, Straub SG, Yajima H, Sharp GW: Triggering and augmentation mechanisms, granule pools, and biphasic insulin secretion. Diabetes 51 (Suppl. 1):S83-S90, 2002

49. Gonzalo S, Linder ME: SNAP-25 palmitoylation and plasma membrane targeting require a functional secretory pathway. Mol Biol Cell 9:585-597, 1998

50. Chapman ER, Blasi J, An S, Brose N, Johnston PA, Sudhof TC, Jahn R: Fatty acylation of synaptotagmin in PC12 cells and synaptosomes. Biochem Biophys Res Commun 225:326-332, 1996

51. Hu L, Deeney JT, Nolan CJ, Peyot ML, Ao A, Richard AM, Luc E, Faergeman NJ, Knudsen J, Guo W, Sorhede-Winzell M, Prentki M, Corkey BE: Regulation of lipolytic activity by long-chain acyl-coenzyme A in islets and adipocytes. Am J Physiol Endocrinol Metab 289:E1085-E1092, 2005

52. Peter-Riesch B, Fathi M, Schlegel W, Wollheim CB: Glucose and carbachol generate 1,2-diacylglycerols by different mechanisms in pancreatic islets. J Clin Invest 81:1154-1161, 1988

53. Prentki M, Matschinsky FM: Ca2+, cAMP, and phospholipid-derived messengers in coupling mechanisms of insulin secretion. Physiol Rev 67:1185-1248, 1987

54. Rhee JS, Betz A, Pyott S, Reim K, Varoqueaux F, Augustin I, Hesse D, Sudhof TC, Takahashi M, Rosenmund C, Brose N: Beta phorbol ester- and diacylglycerol-induced augmentation of transmitter release is mediated by Munc13s and not by PKCs. Cell 108:121-133, 2002

55. Sheu L, Pasyk EA, Ji J, Huang X, Gao X, Varoqueaux F, Brose N, Gaisano HY: Regulation of insulin exocytosis by Munc13-1. J Biol Chem 278: 27556-27563, 2003

56. Kwan EP, Xie L, Sheu L, Nolan CJ, Prentki M, Betz A, Brose N, Gaisano HY: Munc13-1 deficiency reduces insulin secretion and causes abnormal glucose tolerance. Diabetes 55:1421-1429, 2006

57. Huijbregts RP, Topalof L, Bankaitis VA: Lipid metabolism and regulation of membrane trafficking. Traffic 1:195-202, 2000

58. Soga T, Ohishi T, Matsui T, Saito T, Matsumoto M, Takasaki J, Matsumoto S, Kamohara M, Hiyama H, Yoshida S, Momose K, Ueda Y, Matsushime H, Kobori M, Furuichi K: Lysophosphatidylcholine enhances glucose-dependent insulin secretion via an orphan G-protein-coupled receptor. Biochem Biophys Res Commun 326:744-751, 2005

59. Lindvall H, Nevsten P, Strom K, Wallenberg R, Sundler F, Langin D, Winzell MS, Holm C: A novel hormone-sensitive lipase isoform expressed in pancreatic beta-cells. J Biol Chem 279:3828-3836, 2004

60. Mulder H, Holst LS, Svensson H, Degerman E, Sundler F, Ahren B, Rorsman P, Holm C: Hormone-sensitive lipase, the rate-limiting enzyme in triglyceride hydrolysis, is expressed and active in beta-cells. Diabetes 48:228-232, 1999

61. Winzell MS, Svensson H, Arner P, Ahren B, Holm C: The expression of hormone-sensitive lipase in clonal beta-cells and rat islets is induced by long-term exposure to high glucose. Diabetes 50:2225-2230, 2001

62. Fex M, Olofsson CS, Fransson U, Bacos K, Lindvall H, Sorhede-Winzell M, Rorsman P, Holm C, Mulder H: Hormone-sensitive lipase deficiency in mouse islets abolishes neutral cholesterol ester hydrolase activity but leaves lipolysis, acylglycerides, fat oxidation, and insulin secretion intact. Endocrinology 145:3746-3753, 2004

63. Zechner R, Strauss JG, Haemmerle G, Lass A, Zimmermann R: Lipolysis: pathway under construction. Curr Opin Lipidol 16:333-340, 2005

64. Raben DM, Baldassare JJ: A new lipase in regulating lipid mobilization: hormone-sensitive lipase is not alone. Trends Endocrinol Metab 16:35-36, 2005

65. Wolf G: The mechanism and regulation of fat mobilization from adipose tissue: desnutrin, a newly discovered lipolytic enzyme. Nutr Rev 63:166 170,2005

66. Baulande S, Lasnier F, Lucas M, Pairault J: Adiponutrin, a transmembrane protein corresponding to a novel dietary- and obesity-linked mRNA specifically expressed in the adipose lineage. J Biol Chem 276:3333633344,2001

67. Lake AC, Sun Y, Li JL, Kim JE, Johnson JW, Li D, Revett T, Shih HH, Liu W, Paulsen JE, Gimeno RE: Expression, regulation, and triglyceride hydrolase activity of Adiponutrin family members. J Lipid Res 46:24772487,2005

68. Soni KG, Lehner R, Metalnikov P, O’Donnell P, Semache M, Gao W, Ashman K, Pshezhetsky AV, Mitchell GA: Carboxylesterase 3 (EC 3.1.1.1) is a major adipocyte lipase. J Biol Chem 279:40683-40689, 2004

69. Holm C, Osterlund T, Laurell H, Contreras JA: Molecular mechanisms regulating hormone-sensitive lipase and lipolysis. Annu Rev Nutr 20:365393,2000

70. Noel RJ, Antinozzi PA, McGarry JD, Newgard CB: Engineering of glycerolstimulated insulin secretion in islet beta cells: differential metabolic fates of glucose and glycerol provide insight into mechanisms of stimulussecretion coupling. J Biol Chem 272:18621-18627, 1997

71. Brownlee M: A radical explanation for glucose-induced beta cell dysfunction. J Clin Invest 112:1788-1790, 2003

72. Du X, Matsumura T, Edelstein D, Rossetti L, Zsengeller Z, Szabo C, 
Brownlee M: Inhibition of GAPDH activity by poly(ADP-ribose) polymerase activates three major pathways of hyperglycemic damage in endothelial cells. J Clin Invest 112:1049-1057, 2003

73. Krauss S, Zhang CY, Scorrano L, Dalgaard LT, St-Pierre J, Grey ST, Lowell BB: Superoxide-mediated activation of uncoupling protein 2 causes pancreatic beta cell dysfunction. J Clin Invest 112:1831-1842, 2003

74. Green K, Brand MD, Murphy MP: Prevention of mitochondrial oxidative damage as a therapeutic strategy in diabetes. Diabetes 53 (Suppl. 1): S110-S118, 2004

75. Ramanadham S, Gross RW, Han X, Turk J: Inhibition of arachidonate release by secretagogue-stimulated pancreatic islets suppresses both insulin secretion and the rise in beta-cell cytosolic calcium ion concentration. Biochemistry 32:337-346, 1993

76. Ramanadham S, Song H, Bao S, Hsu FF, Zhang S, Ma Z, Jin C, Turk J: Islet complex lipids: involvement in the actions of group VIA calcium-independent phospholipase $\mathrm{A}_{2}$ in beta-cells. Diabetes 53 (Suppl. 1):S179-S185, 2004

77. Song K, Zhang X, Zhao C, Ang NT, Ma ZA: Inhibition of Ca2+-independent phospholipase A2 results in insufficient insulin secretion and impaired glucose tolerance. Mol Endocrinol 19:504-515, 2005

78. Akiba S, Sato T: Cellular function of calcium-independent phospholipase A2. Biol Pharm Bull 27:1174-1178, 2004

79. Ramanadham S, Song H, Hsu FF, Zhang S, Crankshaw M, Grant GA, Newgard CB, Bao S, Ma Z, Turk J: Pancreatic islets and insulinoma cells express a novel isoform of group VIA phospholipase A2 (iPLA2 beta) that participates in glucose-stimulated insulin secretion and is not produced by alternate splicing of the iPLA2 beta transcript. Biochemistry 42 : 13929-13940, 2003

80. Blank ML, Smith ZL, Snyder F: Arachidonate-containing triacylglycerols: biosynthesis and a lipolytic mechanism for the release and transfer of arachidonate to phospholipids in HL-60 cells. Biochim Biophys Acta 1170:275-282, 1993

81. Cook HW, Spence MW: Triacylglycerol as a precursor in phospholipid biosynthesis in cultured neuroblastoma cells: studies with labeled glucose, fatty acid, and triacylglycerol. Can J Biochem Cell Biol 63:919-926, 1985

82. Igal RA, Coleman RA: Acylglycerol recycling from triacylglycerol to phospholipid, not lipase activity, is defective in neutral lipid storage disease fibroblasts. J Biol Chem 271:16644-16651, 1996

83. Wolf BA, Pasquale SM, Turk J: Free fatty acid accumulation in secretagogue-stimulated pancreatic islets and effects of arachidonate on depolarization-induced insulin secretion. Biochemistry 30:6372-6379, 1991

84. Jenkins CM, Mancuso DJ, Yan W, Sims HF, Gibson B, Gross RW: Identification, cloning, expression, and purification of three novel human calcium-independent phospholipase A2 family members possessing triacylglycerol lipase and acylglycerol transacylase activities. J Biol Chem 279:48968-48975, 2004

85. Balsinde J, Dennis EA: Bromoenol lactone inhibits magnesium-dependent phosphatidate phosphohydrolase and blocks triacylglycerol biosynthesis in mouse P388D1 macrophages. J Biol Chem 271:31937-31941, 1996

86. Bao S, Bohrer A, Ramanadham S, Jin W, Zhang S, Turk J: Effects of stable suppression of group VIA phospholipase A2 expression on phospholipid content and composition, insulin secretion, and proliferation of INS-1 insulinoma cells. J Biol Chem 281:187-198, 2006

87. Juhl K, Hoy M, Olsen HL, Bokvist K, Efanov AM, Hoffmann EK, Gromada J: cPLA2alpha-evoked formation of arachidonic acid and lysophospholipids is required for exocytosis in mouse pancreatic beta-cells. $A m \mathrm{~J}$ Physiol Endocrinol Metab 285:E73-E81, 2003

88. Milne HM, Burns CJ, Squires PE, Evans ND, Pickup J, Jones PM, Persaud SJ: Uncoupling of nutrient metabolism from insulin secretion by overexpression of cytosolic phospholipase A(2). Diabetes 54:116-124, 2005

89. Jones PM, Burns CJ, Belin VD, Roderigo-Milne HM, Persaud SJ: The role of cytosolic phospholipase A(2) in insulin secretion. Diabetes 53 (Suppl. 1):S172-S178, 2004

90. Tomita T, Masuzaki H, Iwakura H, Fujikura J, Noguchi M, Tanaka T, Ebihara K, Kawamura J, Komoto I, Kawaguchi Y, Fujimoto K, Doi R, Shimada Y, Hosoda K, Imamura M, Nakao K: Expression of the gene for a membrane-bound fatty acid receptor in the pancreas and islet cell tumours in humans: evidence for GPR40 expression in pancreatic beta cells and implications for insulin secretion. Diabetologia 49:962-968, 2006

91. Shapiro H, Shachar S, Sekler I, Hershfinkel M, Walker MD: Role of GPR40 in fatty acid action on the beta cell line INS-1E. Biochem Biophys Res Commun 335:97-104, 2005

92. Steneberg P, Rubins N, Bartoov-Shifman R, Walker MD, Edlund H: The FFA receptor GPR40 links hyperinsulinemia, hepatic steatosis, and impaired glucose homeostasis in mouse. Cell Metab 1:245-258, 2005

93. Hardy S, St-Onge GG, Joly E, Langelier Y, Prentki M: Oleate promotes the proliferation of breast cancer cells via the $\mathrm{G}$ protein-coupled receptor GPR40. J Biol Chem 280:13285-13291, 2005

94. Overton HA, Babbs AJ, Doel SM, Fyfe MC, Gardner LS, Griffin G, Jackson HC, Procter MJ, Rasamison CM, Tang-Christensen M, Widdowson PS, Williams GM, Reynet C: Deorphanization of a G protein-coupled receptor for oleoylethanolamide and its use in the discovery of small-molecule hypophagic agents. Cell Metab 3:167-175, 2006

95. Yin W, Mu J, Birnbaum MJ: Role of AMP-activated protein kinase in cyclic AMP-dependent lipolysis in 3T3-L1 adipocytes. J Biol Chem 278:4307443080, 2003

96. Dagon Y, Avraham Y, Berry EM: AMPK activation regulates apoptosis, adipogenesis, and lipolysis by eIF2alpha in adipocytes. Biochem Biophys Res Commun 340:43-47, 2006

97. Sato Y, Henquin JC: The K+-ATP channel-independent pathway of regulation of insulin secretion by glucose: in search of the underlying mechanism. Diabetes 47:1713-1721, 1998

98. Liu YJ, Cheng H, Drought H, MacDonald MJ, Sharp GW, Straub SG: Activation of the KATP channel-independent signaling pathway by the nonhydrolyzable analog of leucine, BCH. Am J Physiol Endocrinol Metab 285:E380-E389, 2003

99. Martins EF, Miyasaka CK, Newsholme P, Curi R, Carpinelli AR: Changes of fatty acid composition in incubated rat pancreatic islets. Diabetes Metab 30:21-27, 2004

100. Straub SG, Sharp GW: Glucose-stimulated signaling pathways in biphasic insulin secretion. Diabetes Metab Res Rev 18:451-463, 2002

101. Yaney GC, Korchak HM, Corkey BE: Long-chain acyl CoA regulation of protein kinase $\mathrm{C}$ and fatty acid potentiation of glucose-stimulated insulin secretion in clonal beta-cells. Endocrinology 141:1989-1998, 2000 